\title{
Antioxidant Contents (Vitamin C) of Raw and Blanched Different Fresh Vegetable Samples
}

\author{
Oluwafunmilayo O. Olayinka ${ }^{1 *}$, Ajibola M. Kareem², Isaac B. Ariyo ${ }^{3}$, Stephen K. Omotugba ${ }^{3}$, \\ Adedayo O. Oyebanji ${ }^{4}$ \\ ${ }^{1}$ Department of Environmental Management and Toxicology, College of Environmental Resources Management, University of Ag- \\ riculture, Abeokuta, Nigeria; ${ }^{2}$ Ladoke Akintola University, Ogbomoso, Nigeria; ${ }^{3}$ Federal College of Wildlife Management, New \\ Bussa, Nigeria; ${ }^{4}$ Department of Chemical Sciences, Joseph Ayo Babalola University, Ikeji-Arakeji, Nigeria. \\ Email: fummy2favour@yahoo.com.ph, *olayinkafunmi@gmail.com
}

Received January $28^{\text {th }}, 2011$; revised September $21^{\text {st }}, 2011$; accepted September $30^{\text {th }}, 2011$

\begin{abstract}
The study was aimed to determine the antioxidant contents and the effect of different blanching times ( $5 \mathrm{~min}, 10 \mathrm{~min}$, $15 \mathrm{~min}$ and $20 \mathrm{~min}$ ) on antioxidant contents of three different selected fresh vegetables. Three different types of vegetable were used namely Amaranthus specie locally known as spinach, namely "tete”, (Celosia argentea), soko, (Solonum nodifiorum) and odu, (Telfeira occidentalis) were analyzed for their antioxidant contents. The analysis revealed that raw vegetables have the highest amount of antioxidant contents. Telferia occidentalis had the highest antioxidant content followed by Solonum nodifiorum. It was observed that blanching time had an adverse effect on the antioxidant contents of the blanched vegetables. The antioxidant contents of tete, soko and odu were significantly decreased $(p<0.05)$ after blanching.
\end{abstract}

Keywords: Spinach; Blanching and Antioxidant Contents

\section{Introduction}

Antioxidants are chemical substances that donate an electron to the free radical and convert it to a harmless molecule. Antioxidants intercept free radical and protect cells from the oxidative damage that leads to aging and disease. Antioxidants prevent injury to blood vessel membranes, helping to optimize blood flow to the heart and brain, defend against cancer-causing DNA damage, and help lower the risk of cardiovascular disease. Other essential antioxidants such as vitamin C, E and selenium must be obtained from our diet. Fruits, vegetables and grains are rich sources of antioxidant vitamins.

Epidemiological studies revealed that diets rich in fruits, vegetables and grains are associated with a lower risk of several degenerative disease, such as cancers [1] and cardiovascular diseases [2,3] reported that increased consumption of fruits and vegetables containing high levels of phytochemicals has been recommended to prevent chronic diseases. This association is often attributed to different antioxidant components such as vitamin C, E, carotenoids, lycopenes and other phytochemicals.

Many food composition data bases never take into consideration the fact that concentrations of nutrients and their activity may change through cooking practices such

"Corresponding author. as blanching. This is of great importance's considering that only a small amount of vegetables is consumed in the raw state, whilst most need to be processed for safety and quality. Amaranthus specie locally known as 'tete' is one of the most popular leafy vegetable and abundantly available in the market, and commonly consumed by urban and rural Nigerians. [4] and [5] reported high concentration of antioxidant components for amaranthus specie. This leafy vegetable is generally cooked before being consumed. Losses of antioxidant components from vegetables during cooking have been reported by $[3,6,7]$. However, no research has been carried out to investigate the antioxidant properties of these three different types of vegetables in Nigeria.

This study was to determine the amount of antioxidant present and the effect of blanching time on antioxidant components of these three different selected vegetables.

\section{Materials and Methods}

\subsection{Materials}

Three different types of fresh vegetables: spinach, ( $\mathrm{Ama}$ ranthus specie), soko, (Celosia argentea) and Odu, (Solonum nodifiorum) were purchased from Iree market in Osun State and randomly selected. 


\subsection{Sample Preparation}

Three different vegetables were cleansed under running tap water and excessive water was drained off. Tete ( $\mathrm{Ama}$ ranthus spp), soko (Celosia argentea) and odu (Solonum nodifiorum) of $1 \mathrm{~kg}$ each was chopped into small pieces and divided into four portions for blanching at ( $5 \mathrm{~min}, 10$ min, 15 min and $20 \mathrm{~min}$ ). Blanching was done by simmering the vegetables in boiling water in the ratio of 1 to 5 draining the sample and leaving it to cool at room temperature. They were also analyzed raw. All the raw and blanched samples were lyophilized and homogenized using a blender before being transferred into an airtight container, and kept in the refrigerator prior analysis.

\subsection{Extract Preparation}

The ground samples were extracted with distilled water in the ratio of 1 to 10 . The mixtures were placed in a different conical flask and agitated at $100 \mathrm{rpm}$ with the aid of an orbital shaker. Then each mixture was filtered through a Whatman No. 4 filter paper to obtain a clear extract. Each extract was used for the analysis.

\subsection{Determination of Antioxidant Content}

Antioxidant content of the each sample was determined by the method of [8] using dye 2,6-dichloro phenol-indophenol(DCPIP). The blue dye was titrated against each extract solution until a fainted pink coloured persisted for 15 seconds. This indicated the end points of the titration.

\subsection{Statistical Analysis}

All determinations were triplicate and mean values and standard deviations were reported. Analysis of variance (ANOVA) was performed and the mean separation was done by Duncan multiple range test $(\mathrm{p}<0.05)$ (XPSS Version 14).

\section{Results and Discussion}

\subsection{Effect of Blanching Time on Antioxidant Contents}

Table 1 showed the mean values of blanched vegetables (Tete, Soko, Odu) for $5 \mathrm{~min}$ as $56.7 \pm 4.0,67.7 \pm 5.6$ and $72.0 \pm 6.7$ respectively. Significant differences $(\mathrm{p}<0.05)$ were observed within the values obtained for blanched vegetables with time. Besides temperature, time is one of the critical factors affecting the loss of antioxidant components during blanching. $[9,10]$ reported that blanching for less than $1 \mathrm{~min}$ would retain the high antioxidant activity in green leaves of sweet potatoes. [11] reported a decrease in total antioxidant components when vegetables juices were cooked at $102^{\circ} \mathrm{C}$ for $10 \mathrm{~min}$.

\subsection{Antioxidant Contents of the Raw Vegetables}

From Table 2 Odu had the highest antioxidant content followed by Soko and the least was found in Tete. It implied that raw vegetables were better than that of the blanched counterparts because they have higher antioxidant contents. Cooking practices, such as blanching, may greatly influence the loss of antioxidant components in leafy vegetables $[6,12]$. Spinach has been reported as one of the many vegetables rich in antioxidant components [13-15].

\subsection{Effect of Blanching Time on Three Different Types of Vegetables}

Figure 1 showed that odu had the highest antioxidant contents through out the blanching times. As the blanching time increased the antioxidant contents reduced. This observation agreed with the $[4,5,7]$ reported that the antioxidant components reduced after blanching due to blanching time and temperature. In this study, spinach at 10 min leached out $49 \%$ - $51 \%$ of its antioxidant contents into boiling water. In addition, [14] reported that boiling of fresh-cut spinach for 10 min released 50\% - 60\% of its antioxidant components into the cooking water. Factors such as maturity and variety can also influence the anti-oxidant capacity of vegetables [16,17]. [4] have indicated that boiling processes at above $95^{\circ} \mathrm{C}$ would decompose the antioxidant components of vegetables. Blanching up to 20 min affected the antioxidant components.

\section{Conclusion}

From the above investigation it can be concluded that higher blanching time and higher temperature affected

Table 1. Effect of blanching time on antioxidant contents of three vegetables.

\begin{tabular}{cccc}
\hline Time (Mins) & Tete & Soko & Odu \\
\hline 5 & $56.7 \pm 4.0^{\mathrm{d}}$ & $67.7 \pm 5.6^{\mathrm{c}}$ & $72.0 \pm 6.7^{\mathrm{c}}$ \\
10 & $50.0 \pm 2.3^{\mathrm{c}}$ & $63.3 \pm 4.4^{\mathrm{c}}$ & $67.3 \pm 3.6^{\mathrm{c}}$ \\
15 & $45.0 \pm 1.9^{\mathrm{b}}$ & $52.7 \pm 6.2^{\mathrm{b}}$ & $57.0 \pm 4.2^{\mathrm{b}}$ \\
20 & $35.7 \pm 2.0^{\mathrm{a}}$ & $43.7 \pm 2.2^{\mathrm{a}}$ & $43.0 \pm 1.8^{\mathrm{a}}$ \\
\hline
\end{tabular}

All values are means of triplicate determinations \pm S.D. Means within columns with different superscripts are significantly different $(\mathrm{p}<0.05)$.

Table 2. Antioxidant contents of the raw vegetables.

\begin{tabular}{cc}
\hline Tete & $75.3 \pm 6.7^{\mathrm{a}}$ \\
\hline Soko & $84.9 \pm 2.4^{\mathrm{b}}$ \\
Odu & $90.0 \pm 8.3^{\mathrm{c}}$ \\
\hline
\end{tabular}

All values are means of triplicate determinations \pm S.D. Means within columns with different superscripts are significantly different $(\mathrm{p}<0.05)$. 


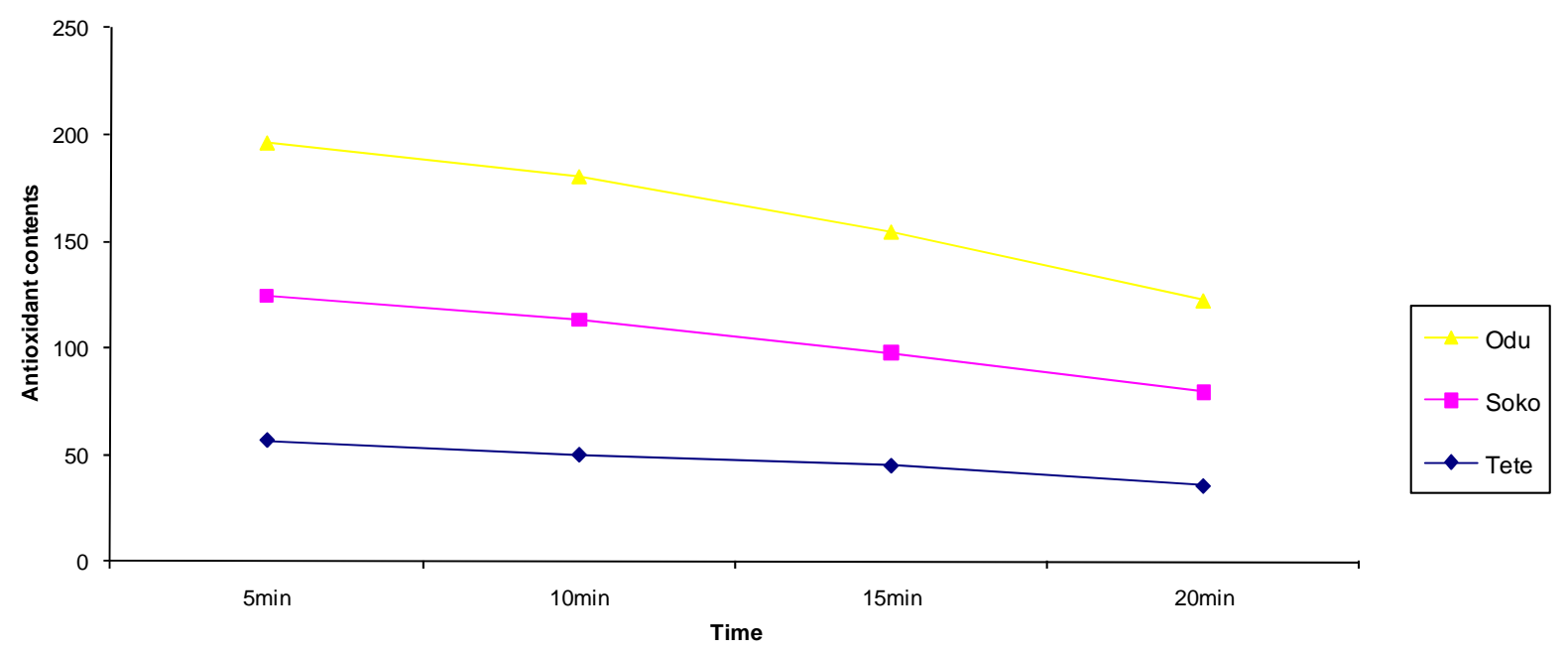

Figure 1. Effect of blanching on three different types of vegetables.

the antioxidant contents (Vitamin C) which was supposed to be derived from the vegetables as vitamin $\mathrm{C}$ supplement. Therefore $1 \mathrm{~min}$ of blanching time is recommended for blanching of vegetables.

\section{REFERENCES}

[1] K. A. Steinmetz and J. D. Potter, "Vegetables, Fruits and Cancer Prevention: A Review,” Journal of America Diet Association, Vol. 96, No. 10, 1996, pp. 1027-1039. doi:10.1016/S0002-8223(96)00273-8

[2] A. Rimm, E. Ascherio, D. Grovannucci, M. J. Spielgelman and W. C. Willett, "Vegetable, Fruit and Cereal Fiber Intake and Risk of Coronary Heart Disease among Men," Journal of the American Medical Association, Vol. 275, No. 6, 1996, pp. 447-451. doi:10.1001/jama.1996.03530300031036

[3] Y. F. Chu, J. Sun, X. Wu and R. H. Liu, "Antioxidant Antiproliferative Activity of Common Vegetables,” Journal of Agricultural and Food Chemistry, Vol. 50, No. 23, 2002, pp. 6910-6916. doi:10.1021/jf020665f

[4] K. J. Hunter and J. M. Fletcher, "The Antioxidant Activity and Composition of Fresh, Frozen, Jarred and Canned Vegetables," Innovative Food Science and Emerging Technology, Vol. 3, No. 4, 2002, pp. 399-406.

[5] I. Amin, Y. Norazaidah and K. I. Emmyhanit, "Antioxidant Activity and Phenolic Content of Raw and Blanching Amaranthus Species," Food Chemistry, Vol. 94, No. 1, 2006, pp. 47-52. doi:10.1016/j.foodchem.2004.10.048

[6] S. K. Yadav and S. Sehgal, "Effect of Home Processing on Ascorbic Acid and $\beta$-Carotene Content of Spinach and Amaranthus Leaves," Plant Foods for Human Nutrition, Vol. 47, No. 2, 1995, pp. 125-131. doi:10.1007/BF01089261

[7] R. Sveto, P. Silvana, K. Jelina, M. Jafranin, R. A. Veletesevic and Peinado, "Losses of Antioxidant Components during Cooking of Vegetables,” Food Chemistry, Vol. 24, 2007, pp. 457-465.

[8] D. Derek, "Vitamin C-Chemistry Review," Chemistry
Review, Vol. 5, No. 5, University of York, York, 1996. http://www.York.ac.uk/depts/chem/chemrev/

[9] K. R. Price, M. Bacom and J. C. Rhodes, "Effect of Storage and Domestic Processing on the Content and Composition of Flavonoids Glucosides in Onion (Allium cepa)," Journal of Agricultural and Food Chemistry, Vol. 45, No. 3, 1997, pp. 938-942. doi:10.1021/jf9605916

[10] C. L. Chu, H. Chang and F. Hsu, "Flavonoid Content of Several Vegetables and Their Antioxidant Activity," Journal of the science of Food and Agriculture, Vol. 80, No. 5, 2000, pp. 561-566.

doi:10.1002/(SICI)1097-0010(200004)80:5<561::AID-JS FA574>3.0.CO;2-\#

[11] K. Papetti, M. Daglia and G. Gazzani, “Anti- and Prooxidant Water Soluble Activity of Chicorium Genus Vegetables and Effect of Thermal Treatment," Journal of Agricultural and Food Chemistry, Vol. 50, No. 16, 2002, pp. 4696-4704. doi:10.1021/jf020123y

[12] T. Nihal, Y. Ferdasari and V. Sedat, "The Effect of Cooking Methods in Total Phenolics and Antioxidant Activity of Selected Green Vegetables,” Food Chemistry, Vol. 93, No. 4, 2005, pp. 713-718.

doi:10.1016/j.foodchem.2004.12.038

[13] G. Cao, E. Sofic and R. L. Prior, “Antioxidant Capacity of Tea and Common Vegetables," Journal of Agricultural and Food Chemistry, Vol. 44, No. 11, 1996, pp. 34263431.

[14] M. I. Gil, F. Ferreres and F. A. Thomas-Barberan, "Effect of Post Harvest Storage and Processing on the Antioxidant Constituents (Flavonoids and Vitamin C) of FreshCut Spinach,” Journal of Agricultural and Food Chemistry, Vol. 47, No. 6, 1999, pp. 2213-2217. doi:10.1021/jf9812001

[15] J. A. Vinson, Y. Hap, X. Su and L. Zubuk, "Phenolic Antioxidant Quantity and Quality in Foods and Vegetables,” Journal of Agricultural and Food Chemistry, Vol. 46, No. 9, 1998, pp. 3630-3634. doi:10.1021/jf980295o

[16] G. Prior, A. Cao, E. Martin, J. M. Sofic and C. O’Brien, "Antioxidant Capacity as Influenced by Total Phenolic and Anthocyanin Content, Maturity and Variety of Vac- 
cinium Species," Journal of Agricultural and Food Chemistry, Vol. 46, No. 7, 1998, pp. 2686-2693.

doi:10.1021/jf980145d
[17] I. Amin, M. Zamaliah and W. F. Chin, "Total Antioxidant Activity and Phenolic Content in Selected Vegetables," Food Chemistry, Vol. 87, No. 4, 2004, pp. 581-586. 